\title{
Empirical Analysis of Exchange Rate Volatility in Emerging African Economies
}

\author{
Abdullahi Murtala Kwarah \\ Department of Economics, University of Zululand, South Africa \\ Corresponding author: qurau30@gmail.com
}

Citation: Kwarah, A.M. (2021). Empirical Analysis of Exchange Rate Volatility in Emerging African Economies Finance \& Economics Review 3(2), 47-70. https://doi.org/10.38157/finance-economics-review.v3i2.333

\section{Research Article}

\begin{abstract}
Purpose: The study examined the empirical nature of the exchange rates volatilities in a few selected African countries, viz. Botswana, Egypt, Morocco, and South Africa.

Method: The study used quarterly data (1990q to 2018q) source from the International Monetary Fund (IMF) financial archive through the Easy-Data website. Thus conducted trend analysis which includes descriptive statistics, autoregressive conditional heteroscedasticity based on the Lagrange Multiplier (ARCH-LM) test, the EGARCH model, and the Constant Conditional Correlation GARCH (CCCGARCH) models. Additionally, test volatility and evaluate the effect of capital flows volatility on exchange rate volatility for all the countries. Further, examine the contagious effect of the exchange rates among the countries.

Result: The investigations revealed that throughout the study, Botswana experienced the highest rate of exchange rate volatility while Morocco was the least in the sample countries. Further, the series are all platykurtic, i.e. there is a reasonable level of fluctuation in the series throughout the study period. In other words, positive (appreciations) are more likely to occur in Morocco, while depreciation is more likely to occur in other countries. The trend analyses also revealed the presence of relative stability for Morocco's exchange rate, while the exchange rate of the remaining countries varied significantly.

Implications: These fluctuations were acute during the period 2001-2018. In this regard, the study has concluded that the exchange rate volatility of these countries was independently determined. Thus, they can ignore monetary and fiscal policy and pursue internal goals, such as full employment, stable growth, and price stability.
\end{abstract}

Keywords: Capital flows, Exchange rate volatility, fixed exchange rate, Flexible exchange rate, Bretton-wood system.

\section{Introduction}

Most African countries' exchange rates ${ }^{1}$ have been characterized by high degrees of rigidity. ${ }^{2}$ Thus, the rigidity in those countries did not protect their currencies from high volatility.

${ }^{1}$ It can be defined as the rate at which one currency is exchanged with the other.

47 Published by Research \& Innovation Initiative Inc., registered with the Michigan Department of Licensing \& Regulatory Affairs, United States (Reg. No. 802790777). 
Exchange rate volatility is an area that has attracted the interest of economic stakeholders, including academics and researchers, since the collapse of the Bretton-Wood system throughout the world. These may be due to its impact on some macroeconomic variables. ${ }^{3}$ IMF $(2009,2017)$ reports that about $85 \%$ of the world economies protect their currencies from free-floating. These countries' decisions might not be unrelated to the devastating strength of exchange rate volatility on macroeconomic variables.

However, in recent times, it was discovered that an exchange rate has a more significant role in shaping macroeconomic policies in the developing, emerging, and developed world. It is incorporated in the policy variable. This is because most central banks are always faced with the exchange rate regime (i.e. fixed or flexible) for their economies.

The choice of exchange rate regime was a subject of intense debate among researchers, academics, and policymakers since the collapse of the Bretton-Wood system. The discussion mainly centered on determining the appropriate policy of exchange rate system capable of delivering a sustainable external and internal balance, irrespective of the sources of shocks (Bravo-Ortega \& Digiovanni, 2006). In this regard, some countries abandoned fixed exchange rates and embarked on floating exchange rates.

Overall, despite the recorded success of the floating exchange rate regime, it is also associated with high risk associated with international trade, uncertainties, and volatility. Volatilities in exchange rates occur as the rates adjust to changing demands and supply conditions in the foreign exchange markets. When frequent and unpredictable, these adjustments cause the exchange rate to be volatile. Within the flexible exchange rate regime, however, these adjustments enable the exchange rate to absorb shocks and shield the domestic economy from the adverse effects of external shocks. Such surprises may come from capital flows. Large capital flows affect the foreign exchange markets by altering the balance of demand and supply of foreign exchange (Keefe 2020).

Unless a central bank can effectively intervene to smoothen the adjustment, as is done under a managed float, volatile capital flows are, therefore, likely to lead to volatility in the exchange rate. Many studies suggest that free-floating of currency is usually associated with exchange rate volatility (Flood \& Rose, 1995; Hasan \& Wallace, 1996). In line with this, the refusal of many countries to adopt a free-floating exchange rate regime in the 1980s and 1990s is an indication of the anxiety of policymakers, which is largely informed by the need to control exchange rate volatility.

The debate mentioned above (fixed vs. flexible exchange rate choice) and the problems discovered associated with the adjustable exchange rate motivate the economic stakeholder to study exchange rate volatility and its impact on various economic variables. In this regard, this study intends to contribute to the debate by analyzing the empirics of exchange rate volatility in the selected African countries (Botswana, Egypt, Morocco, and South Africa). These countries were selected due to the following fact. (1) Morocco, Egypt, and South Africa are the three emerging economies, (2) Botswana's inclusion in the sample represents other African

\footnotetext{
2 For example, it was only in January of 2003 that Egypt's central bank announced a free-floating regime,

${ }^{3}$ For literature on the impact of exchange rate volatility, see Bleaney (1996); Bravo-Ortega and Digiovanni (2006).
}

48 Published by Research \& Innovation Initiative Inc., registered with the Michigan Department of Licensing \& Regulatory Affairs, United States (Reg. No. 802790777). 
developing countries and (3) Availability of data. Precisely, therefore, the study focuses on three key issues.

Firstly, it examines the nature of exchange rate volatility in the selected countries, especially during major global economic events. Secondly, it looks at the effects of capital flows volatility on exchange rate volatility in each chosen country. Furthermore, thirdly, it examines whether there are links between exchange rate volatilities amongst these countries. Thus, the exchange rate volatility here is the propensity for foreign currencies to appreciate or depreciate, affecting the profitability of foreign trades negatively or positively. Volatility happens in any security asset that increases or unpredictably drops in value.

To achieve the study's pre-set objectives, $\mathrm{ARCH}$ and $\mathrm{GARCH}$ and conditional correlation models were employed to analyze the exchange rate trend, volatility, and correlation of the sample countries, with the help of Bollerslev's (1990) methodology.

The following section reviews the related literature, including the issue of exchange rate regime classification and the historical behavior of exchange rate management in the sample countries. Following this, the data and methodology are presented. The paper concludes with the results, interpretation, and findings of the study and a summary and conclusion.

\section{Literature Review}

The exchange rate is a significant macroeconomic dynamic that shakes international trade and the real economy of each country (Morina et al., 2020). The study of exchange rate volatility is one of the critical debates in economics' literature, both empirically and theoretically. Some studies tried to find the general determinants of exchange rate volatility in economics. Despite that, scholars like Hassan (2014) observe that exchange rate volatility determinants are countryspecific.

Some common determining factors are highly associated with triggering volatility, such as 1) globalization, 2) liberalization, and 3) high inflation occurrence. ${ }^{4}$. In addition, some of the literature has tried to establish the nature of the relationship between exchange rate volatility and other macroeconomic variables. Simon (1997), for example, shows a direct positive relationship between exchange rate and current account with inflation.

In his study, Hau (2002) discovers a negative correlation between absolute effective exchange rate volatility and the ratio of trade to GDP. In similar studies, Bravo-Ortega and Di Giovanni (2006) also maintain that exchange rate volatility is negatively related to trade openness and GDP per capita. The study also reveals that trade taxes and index remoteness link positively to the exchange rate. It finally construes that taxes and trade costs, particularly transportation costs, can increase the rate of exchange rate volatility. Devereux and Lane (2003) also discover that exchange rate volatility negatively relates to business cycle asymmetry, financial development, and external debt, thus relating positively to GDP in developing countries.

${ }^{4}$ See Obstfeld (2012); Dornbuschet al. (1995); De Gregorio, Edwards and Valdés (2000); and Gonzaga and Terra (1997).

49 Published by Research \& Innovation Initiative Inc., registered with the Michigan Department of Licensing \& Regulatory Affairs, United States (Reg. No. 802790777). 
Moreover, some studies identify exchange rate volatility as one of the standard features of the financial crisis. ${ }^{5}$ This may be since exchange rate volatility motivated risk aversion and change in perceived risk. These events can lead to too much investment in a particular currency group. Situations like these tend to trigger a currency crisis-further, other studies geared towards forecasting exchange rate levels.

The efforts of Devereux and Lane (2003) have yielded impressive results, leading to the development of many structural models that can capture the pattern. ${ }^{6}$ Despite all these efforts, most of the researchers are focused on the behavior of exchange rates. Thus, they devote more attention to the exchange rate level, with less concern for its volatility.

Exchange rate volatility is a concomitant feature of the global economic condition. Thus, for easy management, policymakers divide exchange rate volatility into two parts: long-term and short-term currency volatility. For them, short-term currency volatility matters most regarding exchange rate speculations.

However, short- and long-term speculations are vital because they help facilitate international trade and foreign direct investments (FDI). They also encourage derivative transactions, on the one hand, and discourage Carry trading; on the other, something that scholars term as highly volatile (Hassan, 2014).

Carry trade is an investment strategy employed by banks, investment fund managers, and traders in the foreign exchange market. Carry trade is identified as shifting a large amount of currency from one country to another to take advantage of interest differentials.

Studies confirm that the choice of exchange rate regime operation is highly associated with exchange rate volatility. Thus, countries operating a floating exchange rate are more likely to have a volatile currency. Using a VAR modeling technique and panel data of 75 developing countries over 23 years (1973-1996), Broda (2004) discovers incidences of considerable shocks in terms of trade and real GDP in the short term. He confirms the presence of adverse shocks, which result in more considerable exchange rate changes in countries that adopted a flexible exchange rate. In a similar study, Aydin (2010), working with a panel data sample of 182 countries to observe the impact of exchange rate volatility from 1973-2008, identifies dynamic changes of the effects of macroeconomics fundamentals on the equilibrium real exchange rate of Sub-Saharan African economies, with few changes in respect of advanced economies.

Focusing on some African countries' literature on the causes of exchange rate volatility, Njugunaet al. (2001) observe that exchange rates in Kenya have witnessed significant volatility since the liberalization of October 1993. The experience of South Africa in respect to liberalization is not different from that of Kenya. Schwab et al. (2015) discovered that South Africa's liberalization of capital account and abandonment of the dual exchange rate system in 1995 led to rand volatility. A more recent experience of the South African exchange rate behavior by Hasan (2014) notes that the brand and volume of portfolio capital flow movements are the major determinants of the country's currency volatility.

${ }^{5}$ See Mc Cauley and Mc Guire (2009); Mc Guire and Von Peter (2009); Kohler (2010) and Coudertet al. (2011).

${ }^{6}$ The champions' studies in these areas are Meese and Rogoff (1983a, b). Other major contributions are from Mark (1995); Sarno and Taylor (2002); Faust and Rogers (2003); Cheung, Chinn, and Pascual (2005); Rossi (2006); Gourinchas and Rey (2007a); Engel et al. (2007); Cerra and Saxena (2008); Molotsova and Papell (2009); Ince (2011) and Molodtsova and Papell (2012).

50 Published by Research \& Innovation Initiative Inc., registered with the Michigan Department of Licensing \& Regulatory Affairs, United States (Reg. No. 802790777). 
For Nigeria, Obadan (2011) identifies the central exchange rate determinants of the country to include weak production base, undiversified nature of the economy, import-dependent production structure, and sluggish foreign capital inflow. Additionally, the study observes unguided trade liberalization policy, over-reliance on the imperfect market system, the weak balance of payments position, loss of monetary policy, and, more importantly, the foreign exchange management system as the determinant of the exchange rate in the country.

Countries whose remittances are the primary source of foreign exchange, or constitute a reasonable percentage of their GDP, are more likely to experience exchange rate volatility. Changes in the flow of remittances mainly cause this. In his study, Abdihet al. (2012) confirms that remittances correlate positively with equilibrium exchange rate appreciation in remittancereceiving countries.

Insah and Chiaraah (2013) identify government expenditure as a significant positive determinant of real exchange rate volatility of the Ghanaian currency (Cedi), adding that domestic and external debts are negative factors of real exchange rate volatility in Ghana. Kamar and Bakardzhieva (2005), in contrast, identify capital flows, lack of adequate investments in the capital market, capital flight, and political instability as the significant contributory factors of the currency (EG pound) volatility in Egypt, which started with the Egyptian central bank's announcement of a free-floating regime in 2002. As for Botswana's pula, the main exchange rate determinants are capital flows, trade, and the change in the price of mining products, most especially diamond.

Conclusively, Baden (2011), Stephen and Sanmi (2012), and Were et al. (2013) observe that most of the developing countries' imports exceed exports. Therefore the demand for foreign exchange (US dollar) often exceeds supply, placing intense upward pressure on the exchange rate. These situations notably contribute to the continuous exchange rate instability of AEE against major currencies (euro, pound, yen, dollar), which are used for commercial transactions - especially the US dollar.

\section{Exchange Rate Regime Classifications}

Prior to 1997, the IMF is the only publisher of information about the exchange rate regime of their members' countries, which is occasionally imprecise. The institution later introduced official exchange rate regime categorization. The IMF is undertaking this categorization through its Annual Report on Exchange Arrangements and Exchange Restrictions (AREA) for its member countries. ${ }^{7}$ This is classified as de jure, a system that is based on the openly stated exchange rate commitment of the monetary authorities in the countries in question (Broda, 2004). The latest IMF classification (AREAER 2014), broadly categorized the exchange rate regime into floaters, intermediate, hard pegs, and currency zones. These are discussed below:

${ }^{7}$ For alternative historical classification, see Levy-Yeyati and Sturzenegger (2005); (Reinhart and Rogoff (2004).

51 Published by Research \& Innovation Initiative Inc., registered with the Michigan Department of Licensing \& Regulatory Affairs, United States (Reg. No. 802790777). 


\subsection{Floaters}

Floaters are divided into two: independently floating and managed float:

3.1.1. Independently floating: This type of exchange rate regime is categorized as "marketdetermined, with any official foreign exchange market intervention aimed at moderating the rate of change and preventing undue fluctuations in the exchange rate, rather than establishing a level for it" (IMF 2006a, p. 25). In other words, it is considered independent and entirely determined by the market forces.

3.1.2. Managed float: The IMF defines it as a regime that has no program (policy) for exchange rate trajectory (track). It also has more authoritative intervention than the independently floating regime. However, the monetary authority tends to influence the exchange rate to ensure a precise track or target. The intervention of the authorities is guided by macroeconomic indicators, such as inflation, the balance of payment, foreign reserves, and capital market development.

\subsection{Intermediate/Soft Pegs}

This can be divided into crawling pegs, exchange rate pegged within horizontal bands, and conventional fixed peg arrangement.

3.2.1. Crawling pegs regime: Under this type of exchange rate, the expectation is for the exchange rate to adjust gradually over time at a fixed rate or in response to economic indicators. This will reduce the pressure of sudden and significant devaluation by intermittently allowing the currency to depreciate (IMF 2006a).

3.2.2. Exchange rate pegged within horizontal bands regime: The exchange rate was within certain limits, usually around a fixed central rate. The sustainability of this system depends solely on the width of the band.

3.2.3. Conventional fixed-peg regime: A central bank will peg its currency to foreign currency or

a currency basket of its choice under this exchange rate. In most cases, the currency is allowed to fluctuate within plus or minus $1 \%$. The monetary authority under this arrangement tries to maintain the fixed parity through direct intervention (sale or purchase of foreign exchange) in the event of market surplus or deficit. In contrast, the monetary authority can make indirect interventions through interest rate policy, the imposition of foreign exchange regulations, the exercise of moral suasion that constrains foreign exchange activity, or intervention by other public institutions (IMF, 2006a).

3.3. Hard Pegs: This can be divided into currency board and dollarized:

3.3.1. Currency board: In this case,

"The basic idea is that the currency board issues currency with a pledge (which could be backed by law) to do two things:

(1) hold a sufficient quantity of another country's currency (the reserve currency) to be able to retire the entire domestic currency supply in the hands of the general public.

(2) exchange domestic currency for the reserve currency at the fixed exchange rate upon demand (which is why currency boards are sometimes called 'currency vending machines'). The currency

52 Published by Research \& Innovation Initiative Inc., registered with the Michigan Department of Licensing \& Regulatory Affairs, United States (Reg. No. 802790777). 
(C) Abdullahi Murtala Kwarah

board, it is hoped, is a bullet-proof fixed exchange rate foreign exchange regime, qualifying it as a hard peg." (de Rosa 2009, p 79).

3.3.2. Dollarize: This refers to a situation in which a country adopts another country's currency, for example, a dollar. For IMF (2014), there are currently about nine countries under this category, out of which seven are using the US dollar - Ecuador, El Salvador, Marshall Islands, Micronesia, Palau, Panama, and Timor-Leste. San Marino and Kiribati use Eastern Caribbean Currency Union (ECCU) and the Australian dollar.

\subsection{Currency zones}

This refers to a conglomeration of countries using the same currency, for example, Eurozone, Central African franc zones, and ECCU.

\section{Exchange Rate Management: Historical Arrangements of the Selected Countries}

Botswana was a member of the Rand Monetary Area (RMA). ${ }^{8}$ The main aim of this organization is to use the rand as a common currency. It was 'pegged' to the US dollar to determine the rand's value, and South Africa's rand was the strong influencer due to its economic might. However, Botswana formally withdrew from RMA in august 1976 and launched its currency, the pula. The pula, at the inception, was pegged to the US dollar at a pula to one dollar fifteen cents (P1/US\$ 1.15), the same level as rand. However, this exchange rate only lasted for about the six-month second quarter of 1977.

The primary condition that necessitated the need for change was the significant appreciation of the rand against the US dollar due to the apparent increase in gold prices. The Botswanan authorities were left with no option but to revisit its exchange rate system. ${ }^{9}$ This time Botswana employed a 'basket of currency pegging' and pegged its currency against the rand and US dollar. ${ }^{10}$.

In May 2005, Botswana introduced a significant change in exchange rate policy that entailed the adoption of its current framework. The change is based on a 'crawling band mechanism'. The crawl rate is based on the differential between the Bank of Botswana's inflation objective and forecast inflation in trading partner countries (IMF, 2014, 2018).

In the case of Morocco, the Bank Al-Maghrib is Morocco's central bank responsible for determining the exchange rate regime and the rate at which the local currency, dirham, should be exchanged and ensure currency stability. After the collapse of the Bretton-Wood system, the IMF describes Morocco's exchange rate system as 'conventional fixed'. In this regard, the local currency was linked to a basket of currencies of the major financial and trading partners by

\footnotetext{
${ }^{8}$ RMA was Southern Africa's monetary regional union that included South Africa, Swaziland, Namibia, Lesotho, and Botswana.

${ }_{9}^{9}$ Pula depreciated against the rand while the rand appreciated against the US dollar. This was a condition that caused inflation increases in Botswana.

${ }^{10}$ The Zimbabwean dollar was introduced in the basket later but dropped in 1994
}

53 Published by Research \& Innovation Initiative Inc., registered with the Michigan Department of Licensing \& Regulatory Affairs, United States (Reg. No. 802790777). 
weighing. ${ }^{11}$. The weighing technique is based on the trading importance of partners. The accession date report of IMF (2014) Article 8 confirmed that Morocco's currency has been partially convertible since 1993. The dirham is freely determined in the interbank foreign exchange market.

To maintain the currency within the predetermined fluctuation margins, Mouley (2012) observers that the central bank of the country operates daily. Ezzahid \& Maouhoub (2014) view that this exchange rate policy allowed monetary authorities to accumulate high levels of foreign exchange reserves. Moreover, to implement a more flexible regime, Morocco has been working with a technical mission from the IIMF. Both parties, Moroccan authorities, and IMF technical mission view that the move would be gradual and to fully liberalize the currency would take years, subject to the market reaction.

South Africa, like Botswana, was a member of the Rand Monetary Area (RMA). As mentioned earlier, the RMA was a regional monetary union comprised of South Africa (the largest economy in the region with the decisive influence of the exchange rate policy in the union), Botswana, Lesotho, Namibia, and Swaziland. The collapse of the Bretton Wood System in 1973 led South Africa to change its exchange rate policy. In June 1974, the country's authorities decided against pegging the rand to the US dollar, and thus announced an independent, managed, floating exchange rate policy. By 1983, the authorities of South Africa obliterated their currency exchange rate system, and in addition, the international central banks refused to renew credit lines for the country. These conditions led to the temporary closure of the country's foreign-exchange market. Subsequently, in 1985, the rand collapsed to its worst level versus the dollar since its initiation due to economic sanctions and disinvestment in protest over the apartheid regime (Brown, 1993).

In 1994, the period that marked post-apartheid South Africa, the country witnessed some level of normality and an improvement in international relations. This situation played a crucial role in revitalizing the rand value against the US dollar, which was downward since the early 1980s. The Asian currency crisis and the political uncertainties associated with the country's national election in 1999 pushed the currency exchange rate value further down against the major currencies (euro, US dollar, pound sterling). Furthermore, South Africa happens to be so integrated into the global financial system, and the September 11 attacks of 2001on the World Trade (WTC) Centre in the USA. The attack on WTC pushed the rand exchange rate to the US dollar to its worst level ever, even though the currency recovered a year later (South African Reserve Bank website). An event such as socio-political unrest, debt, power crises, telecommunication crises, and mining sector crises, in addition to European sovereign debt crises and the global financial crisis of 2007, had massive impacts on the South African exchange rate.

High levels of rigidity have characterized the exchange rate policy in Egypt. The country's currency, i.e. Egyptian pound (LE) has been pegged to the US dollar for an extended period. This exchange rate system can consider a fixed but adjustable peg regime from the 1960sto 1990s. The Egyptian authority had kept the exchange rate of the LE to US dollar fixed. By 1991,

11 The euro was weighted 80\% and the USD 20\% (Ezzahid \& Maouhoub, 2014). 
the country shifted its ground to a managed floating exchange rate regime by announcing a crawling peg regime in January 2001. This regime lasted for only two years, to December 2002, within which the exchange rate of the LE was devalued three times. The regime was preceded by another official announcement in 2003 of an exchange rate policy change to float.

Despite Egypt's floating exchange rate regime declaration, the IMF classification in 2004, 2005, and 2006 described the country's exchange rate regime to be managed floating with no predetermined path for the exchange rate. Also, the IMF shifted its country's classifications in 2008 and 2009 by reporting de facto "other conventional fixed peg arrangement" with the exchange rate as a nominal anchor and "managed floating with no predetermined path for exchange rate" respectively.

Furthermore, IMF reclassified the country's exchange rate regime in 2011 as "Craw-Like Arrangement" and in 2012 as a de facto "Stabilized Arrangement". In 2013, the IMF reclassified Egypt's ER regime as a "Craw-Like Arrangement", with the ER used as a nominal anchor (Massoud \& Willett, 2014). In the last quarter of 2008 to the end of the first quarter of 2009, the county experienced a sharp fall in its goods and services' external demand, followed by an episode of a sudden stop in capital flows. Subsequently, this situation affected the LE exchange rate in a negative manner against the US dollar.

\section{Data and Methodology}

Descriptive statistics, ARCH-LM test, the EGARCH model, and the CCC-GARCH model were employed in this study for trend analysis, the test of volatility, evaluation of the effect of capital flows volatility on exchange rate volatility for all the countries, and examining the contagious effect of the exchange rates among the countries respectively. The data used were drawn from the International Monetary Fund (IMF) financial archive (2015) through the Easy-Data website. In subsequent analysis, however, the actual data were used. The data are quarterly, spanning from 1990q1 to 2016q1, for the sample of all the countries drawn. ${ }^{12}$. The data are subject to crosscountry screening.

\subsection{The EGARCH model}

The exponential GARCH model (EGARCH) of Nelson Shao (1991) was employed to estimate the effect of capital flows volatility on exchange rate volatility for all the countries. Thus, due to its advantages over pure GARCH specification. The advantages are:

1. Due to the $\log \theta^{2}{ }_{t}$ automatically turning positive.

2. Asymmetric are allowed under the E GARCH formulation, since if the relationship between volatility and return is negative, $\mathrm{Y}$ will be negative. The conditional variance equation is specified as follows:

${ }^{12}$ For similar volatility studies with quarterly data, see Broto, Diaz-cassou, and Erce (2011), and Mendoza (2010).

55 Published by Research \& Innovation Initiative Inc., registered with the Michigan Department of Licensing \& Regulatory Affairs, United States (Reg. No. 802790777). 


$$
\log \left(\sigma_{t, \varepsilon}^{2}\right)=\gamma+\sum_{j=1}^{q} \xi_{j, \varepsilon}\left|\frac{\varepsilon_{t-j}}{\sqrt{\sigma_{\varepsilon, t-j}^{2}}}\right|+\sum_{j=1}^{\text {Finance \& Economics Review 3(1), } 2021} \zeta_{j, \varepsilon} \frac{\varepsilon_{t-j}}{\sqrt{\sigma_{\varepsilon, t-j}^{2}}}+\sum_{i=1}^{p} \mu_{i} \log \left(\sigma_{\varepsilon, t-i}^{2}\right)
$$

Meanwhile, to evaluate the effect of capital flows volatility on exchange rate volatility for all the countries, FDI volatility and portfolio investment volatility are included as explanatory variables in the variance equation for estimation of the EGARCH model.

\subsection{The CCC-GARCH model}

The constant conditional correlation GARCH (CCC-GARCH) model, proposed by Bollerslev (1990), was employed in this study to examine the contagion effect of the exchange rates among the four countries. The selection of the model was based on its popularity among the multivariate GARCH models, such serving as a benchmark against which other models can be compared. It is also an n-dimensional GARCH model with GARCH processes $W_{t}$, $\mathrm{t}-1$ related to one another with a constant conditional correlation matrix $\rho$. The CCC-GARCH model has the form:

$$
\begin{aligned}
& W_{t, t-1} \sim N_{n}\left(0, \sum_{t, t-1}\right) \\
& \sum_{t, t-1}=\sigma \rho_{t, t-1} \sigma_{t, t-1}
\end{aligned}
$$

Where $\rho$ is a correlation matrix and

$$
\sigma_{t, t-1}=\left(\begin{array}{cccc}
\sqrt{\sigma_{1}^{2}{ }_{t, t-1}} & 0 & \cdots & 0 \\
0 & \sqrt{\sigma_{2}^{2}} & \ddots & 0 \\
\vdots & 0 & \cdots & \vdots \\
0 & 0 & 0 & \sqrt{\sigma_{n t, t-1}^{2}}
\end{array}\right)
$$

The conditional variances $\left(\sigma_{t, t-1}^{2}\right)$ was modeled with univariate GARCH (p, q) process:

$$
\sigma_{t, t-1}^{2}=a_{i}+\sum_{k=1}^{q} \beta_{i, k} W_{i}^{2}+\sum_{k=1}^{q} b_{i, k} \sigma_{t-k, t-k-1}^{2}
$$

In this study, $W$ represents the exchange rates of Botswana, Egypt, Morocco, and South Africa.

\section{Results Interpretations and Findings}

The descriptive statistics of the exchange rates of the four countries are presented in table 4.1. The result shows the mean values of Botswana exchange rate (BEXR,), Egypt exchange rate (EEXR), Moroccan exchange rate (MEXR), and South African exchange rate (SAEXR) are 7.693624, 4.805635, 12.97844, and 3.449939 respectively over the period considered. It implies that, on average, the exchange rate of Morocco is the highest, followed by that of Botswana, Egypt, and South Africa.

The reasonably large margins between the minimum and maximum values of all the variables show significant series variations over the period. However, the result indicates that Botswana's

56 Published by Research E Innovation Initiative Inc., registered with the Michigan Department of Licensing \& Regulatory Affairs, United States (Reg. No. 802790777). 
standard deviations' exchange rate, 3.413932, is the highest, while Morocco's, 0.527856, is the least. Hence, Botswana experienced the highest level of fluctuation in the exchange rate, while Morocco experienced a minor level of exchange rate fluctuation over the period.

The Skewness shows that the exchange rate of Morocco is negatively skewed while all others are positively skewed. Regarding the kurtosis, the distribution of a series is leptokurtic when the kurtosis is more significant than three, and it is platykurtic when the kurtosis is less than three. Hence, all the series are platykurtic (i.e. evidence of fatter tail than the normal distribution).

The Jaque-Bera statistics are not significant (probability value of the statistics is greater than $5 \%$ ) for all the series except SAEXR, indicating that all the series, except SAEXR, are typically distributed. The characteristics of the exchange rate series of all the countries show a level of fluctuation over the period. Therefore, studying their movements and assessing the impact of capital flow on the exchange rates becomes essential.

Table 1: Descriptive Statistics

\begin{tabular}{|lllll|}
\hline Statistics & $\begin{array}{l}\text { HP-filtered exchange } \\
\text { rate of Botswana } \\
\text { (HPBEXR) }\end{array}$ & $\begin{array}{l}\text { H } \\
\text { exchange rate of Egypt } \\
\text { (HPBEXR) }\end{array}$ & $\begin{array}{l}\text { HP-filtered HP-filtered exchange } \\
\text { rate of } \\
\text { (HPMEXR) }\end{array}$ & $\begin{array}{l}\text { Morocco } \\
\text { rate of South Africa } \\
\text { (HPSAEXR) }\end{array}$ \\
\hline Mean & 7.693624 & 4.805635 & 12.97844 & 3.449939 \\
\hline Median & 7.377249 & 5.164915 & 12.95001 & 3.371279 \\
\hline Maximum & 14.78481 & 7.842579 & 13.86725 & 4.952546 \\
\hline Minimum & 2.350906 & 2.037740 & 11.59927 & 2.615213 \\
\hline Std. Dev. & 3.413932 & 1.495672 & 0.527856 & 0.727740 \\
\hline Skewness & 0.262259 & 0.055027 & -0.247387 & 0.535465 \\
\hline Kurtosis & 2.079342 & 1.865547 & 2.733715 & 2.053456 \\
\hline Jarque-Bera & 4.865162 & 5.629417 & 1.368070 & 8.852294 \\
\hline Probability & 0.087810 & 0.059922 & 0.504577 & 0.011960 \\
\hline Sum & 800.1368 & 499.7860 & 1349.758 & 358.7937 \\
\hline Observations & 104 & 104 & 104 & 104 \\
\hline
\end{tabular}

Note: HP filter was used to detrend the series.

Source: Author's computation.

\section{Trend Analysis}

In order to examine the trend of exchange rates of the four countries, a graph of the series was plotted, and the result is displayed in figure 1. The trend shows that the exchange rate of Morocco has been relatively stable, while that of Botswana varied significantly from about 2 to 14 over the period. Also, the exchange rates of Egypt and South Africa vary significantly. Meanwhile, the period 2001 to 2016 experienced more fluctuations than the earlier period of 1990 to 2000. This coincides with the pattern of movement of net cash flows into the countries over the same period. The flows of FDI and portfolio investments (examined in chapter two) are relatively stable from 1990 to 2000 but fluctuate more over the later period. These seemly co-

57 Published by Research E Innovation Initiative Inc., registered with the Michigan Department of Licensing \& Regulatory Affairs, United States (Reg. No. 802790777). 
movements between the exchange rates and net cash flows reinforced the need to evaluate the effect of cash flows volatilities on exchange rate volatilities over the period.
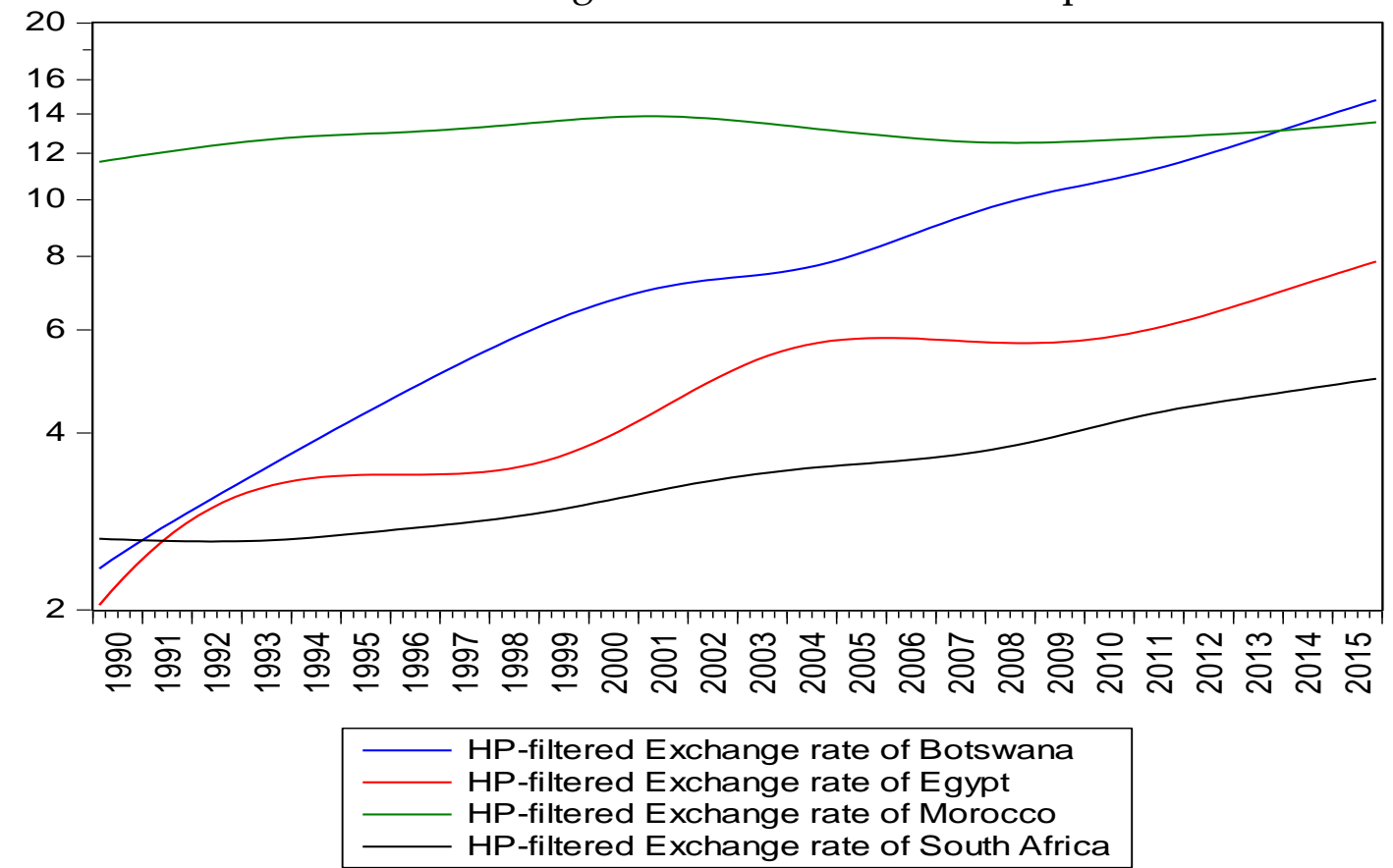

Fig. 1: Trend analysis

Source: Author's presentation of exchange rate data of the sample countries based on IMF data of International Financial Statistics

\section{Exchange Rate Volatility during Major Economic Crisis}

Major economic events in the world often have tremendous effects on exchange rates. Thus, the exchange rate volatilities of the four countries have been calculated according to four major economic crises (the early 1990s recession, the Asian financial crisis of 1996, the Dot-com boom of early 2000, and the global financial crisis in 2007). Table 2 shows the exchange rate volatility during these periods.

Descriptive statistics of exchange rate volatilities have been used to examine the extent of the volatility during each period and compare them. The standard deviation of the exchange rate volatility, estimated by GARCH models, shows the variability in data (for example see, Gabriela \& Georgia 2019). The larger the value of standard deviation that dispersed widely. The more distant the volatility from the average volatility of the period.

The result indicates that the standard deviation of the exchange rate volatility of Botswana is the largest for all the subsamples, except during the early 1990s' recession when the standard deviation of the exchange rate volatility of Morocco is the highest. This implies that Botswana experienced the highest exchange rate volatility during the Asian financial crisis, the Dot-com boom, and the global financial crisis. In contrast, Morocco experienced the highest level of exchange rate volatility during the early 1990 s recession.

Meanwhile, the extent of the exchange rate volatility during the 2007 global financial crisis is shown to be the worst for Botswana, Egypt, and South Africa, respectively, while the Dot-com boom was the worst for Morocco. 
(C) Abdullahi Murtala Kwarah

Table 2: Exchange rate volatility during significant world economic crisis

\begin{tabular}{|c|c|c|c|c|}
\hline & \multicolumn{4}{|c|}{ Exchange rate volatility } \\
\hline & Botswana & Egypt & Morocco & South Africa \\
\hline \multicolumn{5}{|c|}{ Total sample (1990q1-2015q4) } \\
\hline Mean & 0.112658 & 0.040408 & 0.065813 & 0.003619 \\
\hline Standard deviation & 0.078379 & 0.071861 & 0.021916 & 0.003302 \\
\hline Observations & 104 & 104 & 104 & 104 \\
\hline \multicolumn{5}{|c|}{ Early 1990s Recession (1990q1-1996q4) } \\
\hline Mean & 0.021130 & 0.087075 & 0.066195 & 0.003050 \\
\hline Standard deviation & 0.012560 & 0.121113 & 0.018263 & 0.001633 \\
\hline Observations & 27 & 27 & 27 & 27 \\
\hline \multicolumn{5}{|c|}{ Asian financial crisis (1997) } \\
\hline Mean & 0.074491 & 0.003818 & 0.067728 & 0.003021 \\
\hline Standard deviation & 0.026079 & 0.000653 & 0.019585 & 0.001285 \\
\hline Observations & 12 & 12 & 12 & 12 \\
\hline \multicolumn{5}{|c|}{ Dot-com boom (2000q1-2006q4) } \\
\hline Mean & 0.187234 & 0.038620 & 0.063736 & 0.003482 \\
\hline Standard deviation & 0.056201 & 0.042013 & 0.027444 & 0.003687 \\
\hline Observations & 28 & 28 & 28 & 28 \\
\hline \multicolumn{5}{|c|}{ Global financial crisis (2007q1-2015q4) } \\
\hline Mean & 0.136022 & 0.018995 & 0.066502 & 0.004350 \\
\hline Standard deviation & 0.056240 & 0.013340 & 0.021098 & 0.004224 \\
\hline Observations & 36 & 36 & 36 & 36 \\
\hline
\end{tabular}

Table 3: Result of ARCH test

\begin{tabular}{|l|l|l|l|l|}
\hline TEST & BEXR & EEXR & MEXR & SAEXR \\
\hline F-statistics & $14.40398^{* * *}$ & $29.61543^{* * *}$ & $18.44615^{* * *}$ & $11.99886^{* * *}$ \\
& $(0.0003)$ & $(0.0000)$ & $(0.0000)$ & $(0.0008)$ \\
\hline Obs*R-squared & $12.82849^{* * *}$ & $23.25661^{* * *}$ & $15.84093^{* * *}$ & $10.92764^{* * *}$ \\
& $(0.0003)$ & $(0.0000)$ & $(0.0001)$ & $(0.0009)$ \\
\hline
\end{tabular}

Note: P-values in parenthesis and ${ }^{* * *}$ denotes $1 \%$ level of significance.

Source: Author's computation.

Given the volatile nature of exchange rates, the ARCH LM test was employed to examine the volatility of the series for all the countries. The result, contained in table 3 , shows that both the F-statistics and $\mathrm{Obs}^{*} \mathrm{R}$-squared are statistically significant for the exchange rates of all the countries. This implies the presence of the ARCH effect (volatility) on all the variables. It means, therefore, that the exchange rates of Botswana, Egypt, Morocco, and South Africa are highly volatile over the period considered. 
Table 4: Effect of capital flow volatility on exchange rate volatility for all the countries

\begin{tabular}{|lllll|}
\hline E & EGYPT & MOROCCO & BOTSWANA & S. AFRICA \\
\hline Mean equation & & & & \\
\hline Constant & $-5.797416^{* * *}$ & $-4.422350^{* * *}$ & $-3.437889^{* * *}$ & $-4.710545^{* * *}$ \\
\hline & $(0.0000)$ & $(0.0000)$ & $(0.0000)$ & $(0.0000)$ \\
\hline $\begin{array}{l}\text { Lag of exchange } \\
\text { volatility }\end{array}$ & $-0.594210^{* * *}$ & $-0.570027^{* * *}$ & $7.601967^{* * *}$ & $-0.233433^{* * *}$ \\
\hline & $(0.0000)$ & $(0.0000)$ & & \\
\hline Variance equation & & & & $(0.0000)$ \\
\hline Constant & $-18.46365^{* * *}$ & $-215.0172^{* * *}$ & $-4.180310^{* * *}$ & $-0.775182^{* * *}$ \\
\hline & $(0.0001)$ & $(0.0000)$ & $(0.0000)$ & $(0.0000)$ \\
\hline ARCH term & $1.182181^{* * *}$ & 0.198076 & $-0.498416^{* * *}$ & $-0.141973^{* * *}$ \\
\hline & $(0.0000)$ & 0.5800 & $(0.0000)$ & $(0.0000)$ \\
\hline GARCH term & $0.948733^{* * *}$ & -0.224029 & $0.852119^{* * *}$ & $0.631216^{* * *}$ \\
\hline & $(0.0000)$ & 0.7541 & $(0.0000)$ & $(0.0000)$ \\
\hline Asymmetric term & $-0.902311^{* * *}$ & -0.126322 & $-0.028953^{* * *}$ & $0.142428^{* * *}$ \\
\hline & $(0.0000)$ & 0.5615 & $(0.0397)$ & $(0.0000)$ \\
\hline Volatility of FDI & $0.256268^{* * *}$ & $0.148355^{*}$ & $0.201045^{* * *}$ & $0.006410^{* * *}$ \\
\hline & $(0.0002)$ & 0.0653 & $(0.0000)$ & $(0.0000)$ \\
\hline $\begin{array}{l}\text { The volatility of Portfolio } \\
\text { investment }\end{array}$ & $0.188847^{* * *}$ & $5.617586^{* * *}$ & $0.078196^{* * *}$ & $0.006572^{* * *}$ \\
\hline & & & & $(0.0000)$ \\
\hline SIC Value & $(0.0045)$ & 0.0000 & $(0.0000)$ & 2.211450 \\
\hline & 1.802528 & 0.226954 & 1.440596 & \\
\hline
\end{tabular}

Note: $\mathrm{P}$-values in parenthesis and ${ }^{* * *}$ and ${ }^{*}$ denote $1 \%$ and $10 \%$ level of significance, respectively.

Source: Author's computation.

The results of the EGARCH used in finding out the effect of capital flows volatility on exchange rate volatility for all the countries are presented in table 4 . It shows that the coefficients of both volatilities of portfolio investment and volatility of FDI are highly significant for the models in all the countries. This means that both the volatility of portfolio investment and the volatility of FDI significantly affect the exchange rate volatilities of all the countries. In other words, capital flows volatilities are essential drivers of exchange rate volatilities in all the countries considered for this study. The relationship is shown to be positive. This implies that the higher the capital flows volatility, the higher the exchange rate volatilities in each country and vice versa.

To examine the co-movement (contagion effect) of the exchange rates among the four countries, the Constant Conditional Correlations (CCC) model was estimated, and table 5 contains the results. The results suggest that it can neither be said that the exchange rates of Botswana and Morocco, Botswana and South Africa, as well as Morocco and South Africa, are positively related, nor can it be said that the exchange rates of Botswana and Egypt, Egypt and Morocco, as well as Egypt and South Africa, are inversely related since the coefficients of correlation are statistically insignificant. This means there is no significant co-movement among the exchange rates of the countries. 
Table 5: Constant conditional correlations of exchange rates between countries

\begin{tabular}{|lllll|}
\hline Constant Conditional Correlations & Coefficient & $\begin{array}{l}\text { Standard } \\
\text { error }\end{array}$ & Z-statistic & P-value of $\mathbf{Z}$ \\
\hline Correlation of BEXR and EEXR & -.078881 & .0741844 & -1.06 & 0.288 \\
\hline Correlation of BEXR and MEXR & .0357598 & .0753439 & 0.47 & 0.635 \\
\hline Correlation of BEXR and SAEXR & .0001795 & .0910533 & 0.00 & 0.998 \\
\hline Correlation of EEXR and MEXR & -.0510431 & .0677699 & -0.75 & 0.451 \\
\hline Correlation of EEXR and SAEXR & -.0130782 & .0642634 & -0.20 & 0.839 \\
\hline Correlation of MEXR and SAEXR & .1117701 & .1344381 & 0.83 & 0.406 \\
\hline
\end{tabular}

Source: Author's computation.

Alternatively, there is no contagious effect among the exchange rates of the countries considered. So, the volatilities of the countries' exchange rates are independently determined. The exchange rates do not significantly move closely with one another.

\section{Conclusions}

The study achieved its pre-set objectives and concluded the following. Throughout the study, Botswana experienced the highest rate of exchange rate volatility, while Morocco is the least. In addition, Morocco's exchange rate is negatively skewed in contrast to all the remaining counties in the sample positively skewed exchange rate. The series is all platykurtic, i.e. there is a reasonable level of fluctuation in the series throughout the study. Essentially, positive (appreciations) are more likely to occur in Morocco, while adverse events (depreciation) are more likely to occur in others.

The trend analyses reveal the presence of relative stability for Morocco's exchange rate, while the exchange rate of the remaining countries varied significantly. Thus, these fluctuations were more acute during the period 2001-2016.

Furthermore, the study unearthed the exchange rate behavior of the sample countries during the four major global economic events of the early 1990s recession, the Asian financial crisis. Dot-com boom and the 2007 global financial crisis. Thus, three of the sample's countries, i.e. Botswana, Egypt, and South Africa, experienced the worst exchange rate volatility during the global financial crisis of 2007, while Morocco's similar experience was around the Dot-com boom.

To attest to the effect of capital flows volatility (FDI and portfolio) on exchange rate volatility, the study reveals that FDI and portfolio flow volatilities are highly significant for all sample countries' exchange rate volatility models. Thus, all the variables (exchange rate, FDI, and portfolio) volatilities are positively related.

In this regard, the study concludes that the exchange rate volatility of these countries is independently determined. The findings that the exchange rates in these countries are independently determined are most surprising for Egypt, Morocco, and South Africa, which are considered as being in the efficiency-driven phase of development where their economies have

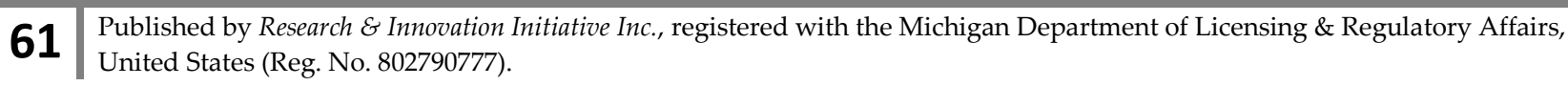


become more competitive with more-efficient production processes and increased product quality and hence one would expect that there ought to be similar inflows and outflows into these economies.

Botswana is considered a factor-driven economy, and hence not sharing a relationship with others is understandable. Such independence is perhaps due to the differences in the size and structure of the economies for the four countries; such countries cannot pursue a standard exchange rate policy. Given that, there is a need for further analysis.

\section{Conflict of Interest: The authors declare no conflict of interest.}

\section{REFERENCES}

Abdih, Y., Chami, R., Dagher, J. \& Montiel, P. (2012). Remittances and institutions: are remittances a curse? World Development, 40, 657-666.

Aydin, B. (2010). Exchange Rate Assessment for Sub-Saharan Economies. IMF Working Paper, 10:162.

Bleaney, M.F. (1996a). Primary commodity prices and the real exchange rate: the case of Australia, 1900-1991. Journal of International Trade and Economic Development, 5, 35-43.

Bollerslev, T. (1990). Modeling the coherence in short-run nominal exchange rates: A multivariate generalized ARCH model. The Review of Economics and Statistics, 72(3), 498-505.

Bravo-Ortega, C. \& Di Giovanni, J. (2006). Remoteness and real exchange rate volatility. IMF Working Paper, 53(1995), 115. Available at: http://julian.digiovanni.ca/Papers/BravoOrtega diGiovanni IMFsp06.pdf.

Broda, C. (2004). Terms of trade and exchange rate regimes in developing countries. Journal of International Economics, 63(1), .31-58.

Cabral, R., Francisco G. C. \& André V. M. (2020). Inflation Targeting and Exchange Rate Volatility in Emerging Markets. Journal Empirical Economics 58 (2), 605-26.

Cerra, V., Chaman \& Saxena, S. (2008). Growth dynamics: the myth of economic recovery. The American Economic Review, 98 (1), 439-457.

Cheung, Y.W., Chinn, M.D. \& Pascual, A.G. (2005). Empirical exchange rate models of the nineties: Are any fit to survive? Journal of International Money and Finance, 24(7), 1150-1175.

Coudert, V., Couharde, C., \& Mignon, V (2011), exchange rate volatility across financial crises. Journal of Banking and Finance, 35, 3010-862.

De Gregorio, J., Edwards, S. \& Valdés, R.O. (2000). Controls on capital inflows: do they work? Journal of Development Economics, 63(1), 59-83.

Devereux, M. \& Lane, P. (2003). Understanding bilateral exchange rate volatility. Journal of International Economics. Available at: http://www.sciencedirect.com/science/article/pii/S0022199602000612

Dornbusch, R., Goldfajn, I., Valdés, R. O., Edwards, S., \& Bruno, M. (1995). Currency Crises and Collapses. Brookings Papers on Economic Activity, 1995(2), 219-293. https://doi.org/10.2307/2534613

Ezzahid, E \& Maouhoub, B. (2014) Capital Account Liberalization and Exchange Rate Flexibility: Scenarios for the Moroccan Case. Discussion Paper No. 2014-18. http://www.economicsejournal.org/economics/discussionpapers/2014-18.

Faust, J. \& Rogers, J. H. (2003). Monetary Policy's Role in Exchange Rate Behaviour, Journal of Monetary Economics 50, 1403-1424.

Flood, R.P. \& Rose. A.K (1995). Fixing Exchange Rates: A Virtual Quest for Fundamentals. Journal of Monetary Economics 36 (1): 3-37.

Gabriela L. N \& Georgia B. (2019) Uncertainty and Exchange Rate Volatility: The Case of Mexico. Working Paper No. 2019-12, Banco de México.

Gonzaga, G. \& Terra M. (1997). Equilibrium Real Exchange Rate, Volatility, and Stabilisation. Journal of Development Economics, 54, 77-100. 
(C) Abdullahi Murtala Kwarah

Gourinchas, P. \& Rey, H. (2007a). World Banker to World Venture Capitalist: US External Adjustment and the Exorbitant Privilege. G7 Current Account Imbalances: Sustainability and Adjustment. Available at: http://www.nber.org/chapters/c0121.pdf

Gourinchas, P. O., \& Rey, H. (2007). International financial adjustment. Journal of political economy, 115(4), 665-703.

Hassan, S. (2014). Speculative Flows, Exchange Rate Volatility and Monetary Policy: South African Experience. South African Reserve Bank Working Paper Series WP/15/02 Available at: https://www.resbank.co.za/content/dam/sarb/publications/working-papers/2015/6610/WP1502.pdf

Hau, H. (2002). Real Exchange Rate Volatility and Economic Openness: Theory and Evidence. Journal of Money, Credit and Banking, 34(3), 611-630.

Herbst, E., P. \&. Johannsen, B., .K. (2020). Bias in Local Projections. Finance and Economics Discussion Series, Washington DC. https://doi.org/10.17016/ FEDS.2020.010

IMF (2007) Annual Report. https://www.imf.org /IMF /external /pubs / eng /pdf.

IMF (2017) Annual Report. https://www.imf.org / IMF /external /pubs / eng /pdf.

IMF (2000). Exchange Rate Regimes in an Increasingly Integrated World Economy. 00/06, IMF staff. http://www.imf.org/external/np/exr/ib/2000/062600.htm

IMF (2008). De facto Classification of Exchange Rate Regimes and Monetary Policy Frameworks. IMF, April. https://www.imf.org/external/np/mfd/er/2008/eng/0408.htm

IMF (2011). Morocco-Concluding Statement of the 2011 Article IV Consultation. IMF. http://www.imf.org/external/np/ms/2011/071911.htm

IMF (2012). IMF Executive Board Concludes 2012 Article IV Consultation with Morocco. Public Information Notice (PIN) No. 13/13. https://www.imf.org/external/np/sec/pn/2013/pn1313.htm

Ince, O. (2011). Forecasting Exchange Rates Out-of-Sample with Panel Methods and Real-Time Data. Unpublished manuscript. Inoue.

Insah, B. \& Chiaraah, A. (2013). Sources of real exchange rate volatility in the Ghanaian economy. Journal of Economics and International Finance, 5(6), 232-238.

Keefe, H. G. (2020). The impact of exchange rate volatility on inflation targeting monetary policy in emerging and advanced economies. Journal of International Finance, 23 (3), 417-433. https://doi.org/10.1111/infi.12368

Levy-Yeyati, E. \& Sturzenegger, F. (2005). Classifying exchange rate regimes: Deeds vs. words. European Economic Review. 49(6), 1603-1635. https://doi.org/10.1016/j.euroecorev.2004.01.001

Mark, N.C. (1995). Exchange rates and fundamentals: evidence on long-horizon predictability. American Economic Review, 85 (1), 201-218.

Massoud, A. A \& Willett T. D (2014). Egypt's Exchange Rate Regime Policy after the Float. International Journal of Social Science Studies, 2 (4), 1-16.

McGuire, Patrick, von Peter, \& Goetz. (2009). The U.S. dollar shortage in global banking and the international policy response. BIS Working Papers \#291.

Meese, R., \& Rogoff, K. (1983). The Out-of-Sample Failure of Empirical Exchange Rate Models: Sampling Error or Misspecification? In Exchange Rates and International Macroeconomics, University of Chicago Press, pp. 3112.

Miyajima, K. (2020). Exchange rate volatility and pass-through to inflation in South Africa. African. Development Review, VOL. 32. Issue 3, pg. 404-418.

Molodtsova, T. \& Papell, D.H. (2012). Taylor Rule Exchange Rate Forecasting During the Financial Crisis. Monetary and Economic Journal.

Molodtsova, T. \&Papell, D.H., (2009). Out-of-sample exchange rate predictability with Taylor rule fundamentals. Journal International Economics, 77 (2), 167-180.

63 Published by Research \& Innovation Initiative Inc., registered with the Michigan Department of Licensing \& Regulatory Affairs, United States (Reg. No. 802790777). 
Morina, Hysa, E., Ergün, U., Panait, M., \& Voica, M. C. (2020). The Effect of Exchange Rate Volatility on Economic Growth: Case of the CEE Countries. Journal of Risk and Financial Management, 13(8), 177. https://doi.org/10.3390/jrfm13080177

Mouley, S. (2012). Challenges arising from capital account liberalization in the countries of the south Mediterranean region. MEDPROF, Technical Report No. 11/2012.

Njuguna, N. S., Karingi, N. S., Geda, A., \&Were, M. (2001). Kenya's Exchange rate Movement in a Liberalised Environment: An Empirical Analysis. KIPPRA Discussion, p. 10.

Nuru, N. Y. (2020). Monetary and Fiscal Policy Effects in South African Economy. African Journal of Economic and Management Studies. https://doi.org/10.1108/AJEMS-08-2019-0308

Reinhart, Carmen M., \& Kenneth S. Rogoff. (2004). The Modern History of Exchange Rate Arrangements: A Reinterpretation. Quarterly Journal of Economics, 119 (February), 1-48.

Rose, A. K. (1996). Explaining Exchange Rate Volatility: An Empirical Analysis of 'The Holy Trinity' of Monetary Independence, Fixed Exchange Rates, and Capital Mobility. Journal of International Money and Finance, 15 (6), 925-45.

Rossi, B. (2005). Testing long-horizon predictive ability, and the Meese-Rogoff puzzle. International Economic Review $46,61-92$.

Sarno, L., \& Taylor, M.P., (2002). The Economics of Exchange Rates. Cambridge Press.

Schwab, J. (2018). The Mixed blessing of FDI: Two-way capital flows and growth. In North-South Globalization and Foreign Direct Investment. Springer Gabler, Wiesbaden. Available at: https://link.springer.com/chapter/10.1007/978-3-658-22811-8 2

Schwab, J. Burstein, I. \& Coniglio, N. (2015). Private capital flows, official development assistance and remittances to Africa: What, Who Gets. IMF Working Papers, 3(November), p.1. http://elibrary.imf.org/view/IMF001/12650-9781463937737/12650-9781463937737/12650-9781463937737.xml .

Simon W.L.S. (1997). Is There Life Outside the ERM? An Evaluation of the Effects of Sterling's Devaluation on the UK Economy. International Journal of Finance and Economics. 2, 199-216.

Stephen, B. \& Sanmi, O. (2012). The Exchange Rate Determination in Nigeria: The Purchasing Power Parity Option. Mathematical Theory and Modelling, 1(2), 5-22.

(c) 2021 by the authors. Licensee Research \& Innovation Initiative Inc., Michigan, USA. This article is an open-access article distributed under the terms and conditions of the Creative Commons Attribution (CC BY) license (http://creativecommons.org/licenses/by/4.0/). 
(C) Abdullahi Murtala Kwarah

\section{Appendix A}

\section{Arch test}

\begin{tabular}{|c|c|c|c|}
\hline \multicolumn{4}{|c|}{ Heteroskedasticity Test: ARCH (BEXR) } \\
\hline F-statistic & 14.40398 & Prob. F(1,99) & 0.0003 \\
\hline \multicolumn{4}{|c|}{ Heteroskedasticity Test: ARCH (EEXR) } \\
\hline F-statistic & 29.61543 & Prob. $\mathrm{F}(1,99)$ & 0.0000 \\
\hline Obs*R-squared & 23.25661 & Prob. Chi-Square(1) & 0.0000 \\
\hline Obs*R-squared & 12.82849 & Prob. Chi-Square(1) & 0.0003 \\
\hline \multicolumn{4}{|c|}{ Heteroskedasticity Test: ARCH (MEXR) } \\
\hline F-statistic & 18.44615 & Prob. $\mathrm{F}(1,98)$ & 0.0000 \\
\hline Obs*R-squared & 15.84093 & Prob. Chi-Square(1) & 0.0001 \\
\hline \multicolumn{4}{|c|}{ Heteroskedasticity Test: ARCH } \\
\hline F-statistic & 11.99886 & Prob. $F(1,100)$ & 0.0008 \\
\hline Obs*R-squared & 10.92764 & Prob. Chi-Square(1) & 0.0009 \\
\hline
\end{tabular}

Dependent Variable: LOG(VOLBEXR)

Method: ML ARCH - Normal distribution (BFGS / Marquardt steps)

Date: 08/09/18 Time: 06:48

Sample (adjusted): 1990Q3 2016Q1

Included observations: 99 after adjustments

Failure to improve likelihood (non-zero gradients) after 57 iterations

Coefficient covariance computed using an outer product of gradients

Pre sample variance: backcast (parameter $=0.7$ )

$\mathrm{LOG}(\mathrm{GARCH})=\mathrm{C}(3)+\mathrm{C}(4)^{*} \mathrm{ABS}(\mathrm{RESID}(-1) / @ S \mathrm{QRT}(\mathrm{GARCH}(-1)))+$

$\mathrm{C}(5)^{*} \mathrm{RESID}(-1) / @ S Q R T(\mathrm{GARCH}(-1))+\mathrm{C}(6)^{*} \mathrm{LOG}(\mathrm{GARCH}(-1))+$

C(7)*LOG(VOLBNFDI) $+\mathrm{C}(8)^{*}$ LOG(VOLBNPFINV)

\begin{tabular}{|c|c|c|c|c|}
\hline Variable & Coefficient & Std. Error & z-Statistic & Prob. \\
\hline C & -3.437889 & 6.0E-104 & $-5.8 \mathrm{E}+103$ & 0.0000 \\
\hline VOLBEXR(-1) & 7.601967 & 0.260631 & 29.16752 & 0.0000 \\
\hline \multicolumn{5}{|c|}{ Variance Equation } \\
\hline$C(3)$ & -4.180310 & $1.4 \mathrm{E}-103$ & $-3.0 \mathrm{E}+103$ & 0.0000 \\
\hline$C(4)$ & -0.498416 & 0.007280 & -68.46715 & 0.0000 \\
\hline$C(5)$ & -0.028953 & 0.014079 & -2.056465 & 0.0397 \\
\hline$C(6)$ & 0.852119 & $1.2 \mathrm{E}-103$ & $6.9 \mathrm{E}+102$ & 0.0000 \\
\hline $\mathrm{C}(7)$ & 0.201045 & 4.7E-105 & $4.3 \mathrm{E}+103$ & 0.0000 \\
\hline $\mathrm{C}(8)$ & 0.078196 & $2.0 \mathrm{E}-105$ & $4.0 \mathrm{E}+103$ & 0.0000 \\
\hline R-squared & 0.567506 & \multicolumn{2}{|c|}{ Mean dependent var } & -2.360421 \\
\hline Adjusted R-squared & 0.563048 & \multicolumn{2}{|c|}{ S.D. dependent var } & 0.918238 \\
\hline S.E. of regression & 0.606977 & \multicolumn{2}{|c|}{ Akaike info criterion } & 1.230889 \\
\hline Sum squared resid & 35.73689 & \multicolumn{2}{|c|}{ Schwarz criterion } & 1.440596 \\
\hline Log-likelihood & -52.92900 & \multicolumn{2}{|c|}{ Hannan-Quinn criter. } & 1.315737 \\
\hline Durbin-Watson stat & 1.126148 & & & \\
\hline
\end{tabular}




\section{Egypt}

\begin{tabular}{|c|c|c|c|c|}
\hline \multicolumn{5}{|c|}{ Dependent Variable: LOG(VOLEEXR) } \\
\hline \multicolumn{5}{|c|}{ Method: ML ARCH - Normal distribution (BFGS / Marquardt steps) } \\
\hline \multicolumn{5}{|c|}{ Date: 08/09/18 Time: 06:58 } \\
\hline \multicolumn{5}{|c|}{ Sample (adjusted): 1990Q4 2016Q1 } \\
\hline \multicolumn{5}{|c|}{ Included observations: 98 after adjustments } \\
\hline \multicolumn{5}{|c|}{ Failure to improve likelihood (non-zero gradients) after 103 iterations } \\
\hline \multicolumn{5}{|c|}{ Coefficient covariance computed using outer product of gradients } \\
\hline \multicolumn{5}{|c|}{ Pre sample variance: backcast (parameter $=0.7$ ) } \\
\hline \multicolumn{5}{|c|}{$\mathrm{LOG}(\mathrm{GARCH})=\mathrm{C}(4)+\mathrm{C}(5)^{*} \mathrm{ABS}(\mathrm{RESID}(-1) / @ \mathrm{SQRT}(\mathrm{GARCH}(-1)))+$} \\
\hline \multicolumn{5}{|c|}{$\mathrm{C}(6)^{*} \mathrm{RESID}(-1) / @ S Q R T(G A R C H(-1))+\mathrm{C}(7)^{*} \mathrm{LOG}(\mathrm{GARCH}(-1))+$} \\
\hline \multicolumn{5}{|c|}{$\mathrm{C}(8)^{*}$ LOG(VOLENFDI $)+\mathrm{C}(9)^{*}$ LOG(VOLENPFINV) } \\
\hline Variable & Coefficient & Std. Error & z-Statistic & Prob. \\
\hline $\mathrm{C}$ & -5.797416 & 0.441727 & -13.12442 & 0.0000 \\
\hline LOG(VOLEEXR(-1)) & -0.594210 & 0.057735 & -10.29193 & 000 \\
\hline \multicolumn{5}{|c|}{ Variance Equation } \\
\hline $\mathrm{C}(4)$ & -18.46365 & 4.816205 & -3.833652 & 0.0001 \\
\hline$C(5)$ & 1.182181 & 0.212902 & 5.552691 & 0.0000 \\
\hline$C(6)$ & -0.902311 & 0.202790 & -4.449477 & 0.0000 \\
\hline $\mathrm{C}(7)$ & 0.948733 & 0.041514 & 22.85324 & 0.0000 \\
\hline$C(8)$ & 0.256268 & 0.068321 & 3.750934 & 0.0002 \\
\hline $\mathrm{C}(9)$ & 0.188847 & 0.066419 & 2.843287 & 0.0045 \\
\hline R-squared & 0.580682 & Mean dep & endent var & -4.271931 \\
\hline Adjusted R-squared & 0.571855 & S.D. de & ndent var & 1.037793 \\
\hline S.E. of regression & 0.679057 & Akaike in & o criterion & 1.565133 \\
\hline Sum squared resid & 43.80626 & Schwa & riterion & 1.802528 \\
\hline Log-likelihood & -67.69153 & Hannan-C & inn criter. & 1.661155 \\
\hline Durbin-Watson stat & 1.515379 & & & \\
\hline
\end{tabular}


(C) Abdullahi Murtala Kwarah

\section{South Africa}

\begin{tabular}{|c|c|c|c|c|}
\hline \multicolumn{5}{|c|}{ Dependent Variable: LOG(VOLSAEXR) } \\
\hline \multicolumn{5}{|c|}{ Method: ML ARCH - Normal distribution (BFGS / Marquardt steps) } \\
\hline \multicolumn{5}{|c|}{ Date: 08/09/18 Time: 07:14 } \\
\hline \multicolumn{5}{|c|}{ Sample (adjusted): 1990Q3 2015Q1 } \\
\hline \multicolumn{5}{|c|}{ Included observations: 99 after adjustments } \\
\hline \multicolumn{5}{|c|}{ Failure to improve likelihood (non-zero gradients) after 45 iterations } \\
\hline \multicolumn{5}{|c|}{ Coefficient covariance computed using the outer product of gradients } \\
\hline \multicolumn{5}{|c|}{ Pre sample variance: backcast (parameter $=0.7$ ) } \\
\hline \multicolumn{5}{|c|}{$\mathrm{LOG}(\mathrm{GARCH})=\mathrm{C}(4)+\mathrm{C}(5)^{*} \mathrm{ABS}(\mathrm{RESID}(-1) / @ \mathrm{SQRT}(\mathrm{GARCH}(-1)))+$} \\
\hline \multicolumn{5}{|c|}{$\mathrm{C}(6)^{*} \mathrm{RESID}(-1) / @ S Q R T(G A R C H(-1))+\mathrm{C}(7) * \mathrm{LOG}(\mathrm{GARCH}(-1))+$} \\
\hline \multicolumn{5}{|c|}{$\mathrm{C}(8)^{*}$ LOG(VOLSNFDI $)+\mathrm{C}(9)^{*}$ LOG(VOLSNPFINV) } \\
\hline Variable & Coefficient & Std. Error & z-Statistic & Prob. \\
\hline$@$ @QRT(GARCH) & -3.989420 & 6.9E-104 & $-5.8 \mathrm{E}+103$ & 0.0000 \\
\hline $\mathrm{C}$ & -4.710545 & $9.8 \mathrm{E}-104$ & $-4.8 \mathrm{E}+103$ & 0.0000 \\
\hline LOG(VOLSAEXR(-1)) & -0.233433 & $2.5 \mathrm{E}-104$ & $-9.4 \mathrm{E}+102$ & 0.0000 \\
\hline \multicolumn{5}{|c|}{ Variance Equation } \\
\hline$C(4)$ & -0.775182 & $1.4 \mathrm{E}-104$ & $-5.7 E+103$ & 0.0000 \\
\hline$C(5)$ & -0.141973 & 0.002177 & -65.21807 & 0.0000 \\
\hline$C(6)$ & 0.142428 & 0.020591 & 6.917142 & 0.0000 \\
\hline$C(7)$ & 0.631216 & $1.2 \mathrm{E}-103$ & $5.4 \mathrm{E}+102$ & 0.0000 \\
\hline$C(8)$ & 0.006410 & $9.20 \mathrm{E}-05$ & 69.64508 & 0.0000 \\
\hline$C(9)$ & 0.006572 & $8.34 \mathrm{E}-05$ & 78.78076 & 0.0000 \\
\hline R-squared & 0.200714 & Mean del & endent var & -5.864457 \\
\hline Adjusted R-squared & 0.184062 & S.D. dep & ndent var & 0.643095 \\
\hline S.E. of regression & 0.580903 & Akaike in & o criterion & 1.975530 \\
\hline Sum squared resid & 32.39507 & Schwar & criterion & 2.211450 \\
\hline Log-likelihood & -88.78873 & Hannan-C & dinn criter. & 2.070983 \\
\hline Durbin-Watson stat & 1.871332 & & & \\
\hline
\end{tabular}




\section{Morocco}

\begin{tabular}{|c|c|c|c|c|}
\hline \multicolumn{5}{|c|}{ Dependent Variable: LOG(VOLMEXR) } \\
\hline \multicolumn{5}{|c|}{ Method: ML ARCH - Normal distribution (Marquardt / EViews legacy) } \\
\hline \multicolumn{5}{|l|}{ Date: 08/09/18 Time: 07:02 } \\
\hline \multicolumn{5}{|c|}{ Sample (adjusted): 1990Q3 2015Q4 } \\
\hline \multicolumn{5}{|c|}{ Included observations: 102 after adjustments } \\
\hline \multicolumn{5}{|c|}{ Convergence achieved after 259 iterations } \\
\hline \multicolumn{5}{|c|}{ Presample variance: backcast (parameter $=0.7$ ) } \\
\hline \multicolumn{5}{|c|}{$\mathrm{LOG}(\mathrm{GARCH})=\mathrm{C}(3)+\mathrm{C}(4)^{*} \mathrm{ABS}(\mathrm{RESID}(-1) / @ \mathrm{SQRT}(\mathrm{GARCH}(-1)))+$} \\
\hline \multicolumn{5}{|c|}{$\mathrm{C}(5)^{*} \operatorname{RESID}(-1) / @ S Q R T(G A R C H(-1))+\mathrm{C}(6)^{*} \mathrm{LOG}(\mathrm{GARCH}(-1))+$} \\
\hline \multicolumn{5}{|c|}{$\mathrm{C}(7)^{*} \mathrm{LOG}(\mathrm{VOLMNFDI})+\mathrm{C}(8)^{*} \mathrm{LOG}($ VOLMNPFINV) } \\
\hline Variable & Coefficient & Std. Error & z-Statistic & Prob. \\
\hline $\mathrm{C}$ & -4.422350 & 0.295940 & -14.94338 & 0.0000 \\
\hline LOG(VOLMEXR(-1)) & -0.570027 & 0.105240 & -5.416441 & 0.0000 \\
\hline \multicolumn{5}{|c|}{ Variance Equation } \\
\hline$C(3)$ & -215.0172 & 29.08422 & -7.392916 & 0.0000 \\
\hline $\mathrm{C}(4)$ & 0.198076 & 0.357930 & 0.553393 & 0.5800 \\
\hline$C(5)$ & -0.126322 & 0.217566 & -0.580616 & 0.5615 \\
\hline$C(6)$ & -0.224029 & 0.715184 & -0.313246 & 0.7541 \\
\hline$C(7)$ & 0.148355 & 0.080496 & 1.842998 & 0.0653 \\
\hline $\mathrm{C}(8)$ & 5.617586 & 0.706723 & 7.948783 & 0.0000 \\
\hline R-squared & 0.325208 & Mean dep & endent var & -2.817815 \\
\hline Adjusted R-squared & 0.318460 & S.D. depe & ndent var & 0.285692 \\
\hline S.E. of regression & 0.235854 & Akaike in & o criterion & 0.021073 \\
\hline Sum squared resid & 5.562723 & Schwarz & criterion & 0.226954 \\
\hline Log-likelihood & 6.925254 & Hannan-Q & uinn criter. & 0.104441 \\
\hline Durbin-Watson stat & 2.047313 & & & \\
\hline
\end{tabular}

\section{Subsample statistics Full sample}

\begin{tabular}{|ccccc|}
\hline & VBEXR & VEEXR & VMEXR & VSAEXR \\
\hline Mean & 0.112658 & 0.040408 & 0.065813 & 0.003619 \\
\hline Median & 0.109600 & 0.014248 & 0.066148 & 0.002475 \\
\hline Maximum & 0.310460 & 0.522431 & 0.136854 & 0.020251 \\
\hline Minimum & 0.005340 & 0.002852 & 0.024609 & 0.000889 \\
\hline Std. Dev. & 0.078379 & 0.071861 & 0.021916 & 0.003302 \\
\hline Skewness & 0.472013 & 4.143597 & 0.629859 & 2.932463 \\
\hline Kurtosis & 2.388459 & 24.04413 & 3.646342 & 12.77989 \\
\hline Jarque-Bera & 5.429675 & 2195.329 & 8.603269 & 558.1039 \\
\hline Probability & 0.066216 & 0.000000 & 0.013546 & 0.000000 \\
\hline Sum & 11.60375 & 4.162009 & 6.778691 & 0.372714 \\
\hline Sum Sq. Dev. & 0.626615 & 0.526730 & 0.048992 & 0.001112 \\
\hline Observations & 103 & 103 & 103 & 103 \\
\hline
\end{tabular}


(C) Abdullahi Murtala Kwarah

\section{Black Monday}

\begin{tabular}{|ccccc|}
\hline & VBEXR & VEEXR & VMEXR & VSAEXR \\
\hline Mean & 0.021130 & 0.087075 & 0.066195 & 0.003050 \\
\hline Median & 0.019916 & 0.030763 & 0.068366 & 0.002654 \\
\hline Maximum & 0.048790 & 0.522431 & 0.107926 & 0.008864 \\
\hline Minimum & 0.005340 & 0.005397 & 0.030409 & 0.001308 \\
\hline Std. Dev. & 0.012560 & 0.121113 & 0.018263 & 0.001633 \\
\hline Skewness & 0.423972 & 2.150489 & 0.146384 & 1.947661 \\
\hline Kurtosis & 2.083178 & 7.597993 & 3.149513 & 7.190066 \\
\hline & & & & \\
\hline Jarque-Bera & 1.754518 & 44.59493 & 0.121576 & 36.82146 \\
\hline Probability & 0.415921 & 0.000000 & 0.941023 & 0.000000 \\
\hline & & & & \\
\hline Sum & 0.570509 & 2.351035 & 1.787254 & 0.082361 \\
\hline Sum Sq. Dev. & 0.004101 & 0.381375 & 0.008672 & $6.93 \mathrm{E}-05$ \\
\hline Observations & 27 & 27 & 27 & 27 \\
\hline
\end{tabular}

Asian financial crisis

\begin{tabular}{|ccccc|}
\hline & VBEXR & VEEXR & VMEXR & VSAEXR \\
\hline Mean & 0.074491 & 0.003818 & 0.067728 & 0.003021 \\
\hline Median & 0.069898 & 0.003656 & 0.067227 & 0.002753 \\
\hline Maximum & 0.114153 & 0.005026 & 0.110758 & 0.005134 \\
\hline Minimum & 0.039126 & 0.003040 & 0.039443 & 0.001277 \\
\hline Std. Dev. & 0.026079 & 0.000653 & 0.019585 & 0.001285 \\
\hline Skewness & 0.209010 & 0.544980 & 0.562583 & 0.221182 \\
\hline Kurtosis & 1.630272 & 2.052828 & 3.120748 & 1.744558 \\
\hline Jarque-Bera & 1.025448 & 1.042573 & 0.640290 & 0.885911 \\
\hline Probability & 0.598862 & 0.593756 & 0.726044 & 0.642136 \\
\hline Sum & 0.893893 & 0.045818 & 0.812737 & 0.036254 \\
\hline Sum Sq. Dev. & 0.007481 & $4.68 \mathrm{E}-06$ & 0.004219 & $1.82 \mathrm{E}-05$ \\
\hline Observations & 12 & 12 & 12 & 12 \\
\hline
\end{tabular}


Finance \& Economics Review 3(1), 2021

\section{Economic boom}

\begin{tabular}{|ccccc|}
\hline & VBEXR & VEEXR & VMEXR & VSAEXR \\
\hline Mean & 0.187234 & 0.038620 & 0.063736 & 0.003482 \\
\hline Median & 0.167666 & 0.026102 & 0.057928 & 0.002175 \\
\hline Maximum & 0.310460 & 0.172809 & 0.125452 & 0.020251 \\
\hline Minimum & 0.119087 & 0.002852 & 0.024609 & 0.000889 \\
\hline Std. Dev. & 0.056201 & 0.042013 & 0.027444 & 0.003687 \\
\hline Skewness & 0.822039 & 2.018124 & 0.763626 & 3.574481 \\
\hline Kurtosis & 2.364677 & 6.355346 & 2.708436 & 16.59587 \\
\hline Jarque-Bera & 3.624404 & 32.14125 & 2.820425 & 275.2813 \\
\hline Probability & 0.163294 & 0.000000 & 0.244091 & 0.000000 \\
\hline Sum & 5.242565 & 1.081347 & 1.784614 & 0.097507 \\
\hline Sum Sq. Dev. & 0.085281 & 0.047657 & 0.020336 & 0.000367 \\
\hline Observations & 28 & 28 & 28 & 28 \\
\hline
\end{tabular}

\section{Global financial crisis}

\begin{tabular}{|ccccc|}
\hline & VBEXR & VEEXR & VMEXR & VSAEXR \\
\hline Mean & 0.136022 & 0.018995 & 0.066502 & 0.004350 \\
\hline Median & 0.127435 & 0.012688 & 0.068237 & 0.002435 \\
\hline Maximum & 0.251706 & 0.055427 & 0.136854 & 0.017673 \\
\hline Minimum & 0.060692 & 0.007210 & 0.024913 & 0.000908 \\
\hline Std. Dev. & 0.056240 & 0.013340 & 0.021098 & 0.004224 \\
\hline Skewness & 0.583183 & 1.185064 & 0.764079 & 1.793394 \\
\hline Kurtosis & 2.144032 & 3.276274 & 4.940901 & 5.485144 \\
\hline Jarque-Bera & 3.139633 & 8.540748 & 9.153540 & 28.56148 \\
\hline Probability & 0.208083 & 0.013977 & 0.010288 & 0.000001 \\
\hline Sum & 4.896780 & 0.683809 & 2.394086 & 0.156592 \\
\hline Sum Sq. Dev. & 0.110704 & 0.006229 & 0.015579 & 0.000625 \\
\hline Observations & 36 & 36 & 36 & 36 \\
\hline
\end{tabular}

